\title{
Association studies between grain yield and agronomic traits of a MARS maize (Zea mays L.) population under drought and non-stress condition
}

\author{
Folusho BANKOLE ${ }^{12}$, Abebe MENKIR ${ }^{3}$, Gbadebo OLAOYE ${ }^{1}$, Oloruntoba OLAKOJO ${ }^{1}$, Gedil MELAKU ${ }^{4}$
}

Received May 06, 2019; accepted August 19, 2019.

Delo je prispelo 06. maja 2019, sprejeto 19. avgusta 2019.

\begin{abstract}
Association studies between grain yield and agronomic traits of a MARS maize (Zea mays L.) population under drought and non-stress condition

Abstract: The study aimed at examining the associations between yield and other traits under drought stress and non-stress conditions. A total of 150 MARS testcrosses were evaluated under both conditions at the International Institute of Tropical Agriculture substation for two years under during the dry season. Genotypic and phenotypic correlation, multiple stepwise regression and path co-efficient analyses were carried out to examine the relationship among the traits under both environments. Results showed anthesis-silking interval, days to silking, husk cover and plant aspect were significantly associated with yield under drought condition at both genotypic and phenotypic levels. Yield was positively correlated with plant and ear height but had a negative correlation with plant and ear aspect at both levels under well-watered condition. Regression analysis showed that ears per plant, plant aspect, ear aspect, days to silking, leaf death and plant height had a direct effect on yield, contributing a total of $71.1 \%$ of observed variation under drought, while ears per plant, ear aspect, plant aspect, days to pollen shed, days to silking and plant height contributed about $31.42 \%$ to yield under wellwatered conditions. The study concluded that these traits be used as selection criteria as it will aid improvement of maize yield.
\end{abstract}

Key words: maize; association; grain yield; drought; well-watered; MARS; testcross
Raziskava povezav med pridelkom zrnja in agronomskimi lastnostmi populacij koruze (Zea mays $\mathrm{L}$.) $\mathrm{v}$ razmerah suše in $\mathrm{v}$ nestresnih razmerah

Izvleček: Namen raziskave je bil preučiti povezave med pridelkom zrnja in drugimi lastnostmi koruze v razmerah suše in v nestresnih razmerah. Na International Institute of Tropical Agriculture je bilo ovrednotenih 150 križanj v obeh razmerah $\mathrm{v}$ dveh letih, v sušni sezoni. Genotipska in fenotipska korelacija, postopna multipla regresija in koeficient korelacije med neposredno odvisnimi spremenljivkami so bili opravljeni za preučitev razmerja med lastnostmi $\mathrm{v}$ obeh rastnih razmerah. Rezultati so pokazali, da so bili znaki kot so obdobje anteza-sviljenje, dnevi do sviljenja in pokritost storža značilno povezani s pridelkom v sušnih razmerah na genotipski in fenotipski ravni. Pridelek je bil v pozitivni korelaciji $\mathrm{z}$ višino rastlin in višino storžev na rastlini, a je bil v negativni korelaciji z drugimi aspekti rastline in storža $\mathrm{v}$ razmerah dobre oskrbe $\mathrm{z}$ vodo. Analiza regresije je pokazala, da so imeli znaki kot so število storžev na rastlino, aspekt rastline in storža, dnevi do sviljenja, smrtnost listov in višina rastlin neposreden učinek na pridelek in so prispevali skupaj $71,1 \%$ opažene spremenljivosti v sušnih razmerah, medtem ko so ti isti znaki prispevali le $31,42 \%$ vpliva na pridelek v razmerah dobre oskrbe $\mathrm{z}$ vodo. Na osnovi te raziskave je bilo zaključeno, da bi lahko te lastnosti (znake) uporabili kot selekcijske kriterije, ki bi pomagali izboljšati pridelek koruze.

Ključne besede: koruza; povezava; pridelek zrnja; suša; dobra oskrba z vodo; MARS; testna križanja

1 University of Ilorin, Department of Agronomy, Ilorin, Nigeria

2 Corresponding author, e-mail: bankole.fa@unilorin.edu.ng

3 International Institute of Tropical Agriculture, Maize Improvement Programme, Ibadan, Nigeria

4 International Institute of Tropical Agriculture, Bioscience centre, Ibadan, Nigeria 


\section{INTRODUCTION}

Maize (Zea mays L.) is presently the second most abundant crop in the world (Ort and Long, 2014) and it has a higher yield potential compared with rice and wheat theoretically, being a $\mathrm{C}_{4}$ plant (Gong et al., 2015). Despite its potential, the average grain yield of maize in the West and Central Africa (WCA) sub region is estimated to be $1.8 \mathrm{t} \mathrm{ha}^{-1}$ (www.fao.org), this is quite low compared with the yield recorded by many other regions where maize is grown, both in the developing and developed regions of the world (Semagn et al., 2015). Maize yields in Africa are considerably lower than the world average because the cultivation of maize is often prone to abiotic stresses such as drought and low soil fertility in addition to biotic stresses principal among which are Striga species and stem borers (FAO, 2010). Drought stress is the most restrictive agronomic problem confronting maize production, reducing crop yields particularly in regions of the world faced with water limitation, a region with an appreciable number of resource poor farmers (Mhike et al., 2013). In comparison to other abiotic stress factors, drought is the causative factor for the major losses recorded in crop production (Ober, 2008). Although maize has it origin in the tropics, it is extremely prone to drought and heat, particularly at silk emergence and/or when flowers are ready for pollination (Boyer and Westgate, 2004; Lobell et al., 2011, 2014; Frey et al., 2015). A number of studies have reported a significant decrease in the ear traits and also in the commercial value of maize under drought (Edmeades et al., 1995; Ti-da et al., 2006; Mohammadai et al., 2012). The change in the climate is expected to increase the occasions of drought in Africa (Williams and Funk, 2011), together with the fact that maize production is extending into regions that are predisposed to drought stress (Bankole et al., 2017). The world's grain supply is inadequate compared with the demand for food and feed. Furthermore, a gross limitation in crop production worldwide has been predicted as a result of changes in climate, particularly extreme temperatures and drought (Cooper et al., 2014; Frey et al., 2015; Horton et al., 2015). Consequently, it becomes more difficult for a small-scale producer of maize with little or no access to irrigation facilities, who plants varieties that are susceptible to drought stress in sub-Saharan Africa to survive these myriads of challenges (Derera et al., 2008).

Some maize producers have adjusted their planting dates to fit the rainy season which enables the planting periods to correspond with the outset of the rains. Others producers have substituted maize with tree crops because they are more tolerant of changes in temperature and rainfall regimes (Barimah et al., 2014). Subsequently, improvement of crops for tolerance to drought has become imperative of crops under the changing environmental conditions.

The conventional breeding method which exploits inherent genetic variation and uses selection as a tool to integrate desirable traits into adapted genotypes seems to be the most common method in breeding for drought tolerance (Xoconostle-Cazares et al., 2011). The comparative performance of genotypes under drought stress and non-stressed conditions seem to be a common criterion for identifying desirable genotypes for erratic rain-fed conditions (Nouri et al., 2011). Selection for traits such as yield under drought condition proves more challenging as a result of low heritability for the trait under stress conditions (Edmeades et al., 1999; Venuprasad et al., 2007; Ziyomo and Bernado, 2013) rendering the selection process quite ineffective. However, some secondary traits such as anthesis silking interval and ears per plant show high estimates of heritability and genetic correlations with grain yield under drought stress (Bolaños and Edmeades, 1996; Bänziger and Lafitte, 1997; BaduApraku et al., 2004). Therefore, an estimate of correlation and path coefficient between the primary trait and other component traits influencing yield is requisite for selection of superior maize genotypes for a successful breeding programme

Correlation coefficient analyses are useful for selecting the traits that influence grain yield simultaneously (Menkir, 2008). It usually exploits the degree of association among continuous traits (Malik et al., 2005). Despite the usefulness of these estimates in the understanding of complex traits such as grain yield, direct and indirect influences of these traits on productivity are not defined (Baretta et al., 2016). In this context, a method was proposed by Wright (1921) which partitions correlation coefficients into the components of direct and indirect effects known as path coefficient analysis. The analysis not only partitions the correlation coefficient into direct and indirect effects, it also provides the information on the actual contribution of a trait on the yield (Dewey and Lu, 1959).

Several maize breeders have used this method for identifying secondary traits as opposed to the use of genetic correlation (Barros et al., 2010; Chinnadurai and Pothraj, 2011; Begum et al., 2016; Baretta et al., 2016, Talabi et al., 2017; Matin et al., 2017). However, the use of path coefficient analysis to identify and validate secondary traits for selection of improved grain yield under water stress and non-stress condition remains a relevant research focus in maize breeding (Bolaños and Edmeades, 1993, 1996; Bänziger and Lafitte, 1997; Badu-Apraku et al., 2004). The study reported herein examined the nature of inter-trait associations between grain yield and other traits under managed drought stress and non-stress con- 
ditions, using genotypic and phenotypic correlations, step-wise multiple linear regression and path co-efficient analyses.

\section{MATERIALS AND METHOD}

\subsection{DEVELOPMENT OF THE MARS POPULATION}

The details of the development of the marker assisted recurrent selection (MARS) population and data collected have been provided in an earlier report (Bankole et al., 2017). Briefly, a MARS population was developed by crossing two elite drought tolerant maize inbreds (DTPL-W-C7-S2-7-1-1-1-1-B-5-B*4 and Babangoyo/ MO17LPA/Babangoyo-23-4-3-3-B*6) selected for desirable agronomic traits, resistance to foliar diseases. The resulting $\mathrm{F}_{1}$ was selfed to generate $\mathrm{F}_{2}$ bulk seeds, which was grown in 50 rows of $5 \mathrm{~m}$ length with a spacing of $0.75 \mathrm{~m}$ and self-pollinated to generate $300 \mathrm{~F}_{2: 3}$ lines. A total of $250 \mathrm{~F}_{2: 3}$ lines from this population were planted each in a row and crossed to an inbred tester of the opposite heterotic group. The testcrosses were evaluated under drought stress (DS) and well watered (WW) conditions at the International Institute of Tropical Agriculture (IITA) Ikenne substation during the dry season in 2014 and 2015.

\subsection{EXPERIMENTAL LAYOUT AND CULTURAL PRACTICES FOR DROUGHT AND WELL-WA- TERED EXPERIMENTS}

A trial which consist of 150 testcrosses of randomly selected $S_{1}$ lines from a MARS population were evaluated under drought and well-watered conditions at Ikenne during the 2014 and 2015 dry seasons. The testcrosses were arranged in a lattice design with two replications. Each of testcross was planted in a single row of $5 \mathrm{~m}$ and $0.75 \mathrm{~m}$ spacing between the rows and the plants were spaced $0.25 \mathrm{~m}$ apart in the rows. In the DS trial, irrigation was withdrawn from six weeks after planting up to the harvest to elicit drought stress at flowering and grain filling stages, whereas the well-watered trial received irrigation until physiological maturity. Compound fertilizer was application at the rates of $60 \mathrm{~kg} \mathrm{~N}, 60 \mathrm{~kg} \mathrm{P}$, and $60 \mathrm{~kg} \mathrm{~K} \mathrm{ha}{ }^{-1}$ was done at the time of sowing and an additional $60 \mathrm{~kg} \mathrm{~N} \mathrm{ha}^{-1}$ was added four weeks later. Gramaxone and atrazine were applied for each of the trial as pre-emergence herbicides at $5.01 \mathrm{ha}^{-1}$ and supplemented with manual weeding to keep the experiments free from weed.

\subsection{DATA COLLECTION}

Days to anthesis (DP) and silking (DS) were recorded in each of the plot as the number of days from sowing to when half of the plants were shedding pollen grains and showed emerged silks, respectively. Anthesis-silking interval (ASI) was computed as the interval in days between silking and anthesis. Plant height (PH) and ear height $(\mathrm{EH})$ were measured in centimetres as the distance from the base of the plant to the height of the first tassel branch and the node bearing the upper ear, respectively. Plant aspect (PA) was rated on a scale of 1 to 5 , where 1 = excellent overall phenotypic appeal and $5=$ poor overall phenotypic appeal. Ear aspect (EA) was scored on a scale of 1 to 5 , where $1=$ clean, uniform, large, and well-filled ears and $5=$ rotten, variable, small, and partially filled ears. Visual leaf death (LD) was scored only under drought at 12 weeks after planting (WAP) on a scale of 1 to 9 , where $1=$ less than $10 \%$ senesced leaf and $9=$ more than $80 \%$ senesced leaf area below the ear. The number of ears per plant (EPP) was the proportion of total number of ears divided by the number of harvested plants. All ears harvested from each plot were shelled to determine percentage moisture and grain yield (GY) adjusted to $15 \%$ moisture.

\subsection{STATISTICAL ANALYSES}

SAS version 9.3 (SAS institute 2011) was used for the regression analyses. The multiple stepwise regression was then used to describe the contributory relationship among the traits under both the drought stress and well-watered environments using the protocol proposed by Mohammadi et al., 2003. The first and second order traits were organized into the path coefficient analysis based on their contribution to the total variation in grain yield with the use of the multiple stepwise regression analysis. Initially all measured traits were regressed on GY and the first order traits were identified by their significant percentage contribution to GY at $5 \%$ probability level. The other traits that made contributions to GY through the first order traits were classified as second order traits. Estimates of genotypic and phenotypic correlation coefficient between GY and other agronomic and yield related traits were carried out using SAS version 9.3 version (SAS Institute, 2011). The Delta method was used to compute the standard errors as proposed by Holland (2006). The genotypic correlation greater than twice the value of its standard error was considered to be significant statistically (Kolawole et al., 2018) 


\section{RESULTS AND DISCUSSION}

The genotypic and phenotypic correlations between grain yield, the primary trait of selection, and other agronomic traits for the MARS testcrosses under drought stress and well-watered conditions are presented in Tables 1 and 2 respectively. For some of the traits such as ear aspect it was not possible to estimate genotypic correlation because of the null values of genetic variance which was identified as 0.00 . The results revealed that though the direction and magnitude of the estimates of both correlations were alike for almost all measured traits, the estimates of genotypic correlation were a little higher than those of the phenotypic correlation. This suggests the presence of environmental influence which is responsible for a reduction in estimates of phenotypic correlation despite the strong association between the traits considered. Similar results were reported by Gazal et al., (2018), who observed higher values for genotypic correlation compared with those of the phenotypic correlation.

Significant $(\rho \leq 0.01)$ but negative genotypic and phenotypic correlations were observed between grain yield (GY) and flowering traits viz: anthesis silking interval (ASI), days to anthesis (DP) and silking (DS) under drought stress condition. This observation suggests that improvement in GY is associated with a reduction in ASI, DS, PA and EA under drought stress condition (Table 1).

Significant $(\rho \leq 0.01)$ but positive genotypic and phenotypic correlations were observed between grain yield (GY) and plant height (PH), and also with ear height (EH). The association between GY and plant aspect (PA) well as between GY and ear aspect (EA) was significant and negative at both genotypic and phenotypic correlations under well-watered condition (Table 2). The improvement in the yield of grains can therefore be associated with an increase in the $\mathrm{PH}$ and $\mathrm{EH}$ under well-watered conditions which suggests that both traits are good predictors of GY. Lodging is however increased when selection is done for increased $\mathrm{PH}$ under nonstressed conditions and this will have a negative impact on GY (Talabi et al., 2017).

Association between ASI, DP, DS, PH, EA and GY under drought stressed and non-stressed conditions have been earlier reported (Bolanos and Edmeades, 1996; Ribaut et al., 1997; Messmer et al., 2009; Zheng et al., 2009 and Liu et al., 2011). Of all the secondary traits measured under drought stress condition only ASI showed significant association with GY at the genotypic level whereas these traits were weakly or not correlated under well-watered condition. This indicates that ASI is a secondary trait that provides the most important adaptive mechanism for drought tolerance in maize. The strong observed correlations of GY with ASI under drought conditions, was in line with the findings of Betran et al. (2003), Cattivelli et al. (2008). Bolanos and Edmeades (1996) reported strong genetic correlations between GY and ASI $(r=-0.60)$ under drought stress and suggested that selection done for GY under drought stress was less efficient than selection for ASI.

The results of the stepwise multiple regression analysis under drought stress conditions showed that EPP, PA, EA, DS, LD and PH had a direct effect which was significant on grain yield with a contribution of about $71.1 \%$ to the total observed variation (Table 3 ). EPP accounted for the largest proportion of the contribution to grain yield under drought stress (52\%) which is an indication that it is the most important trait in determination of grain yield under drought conditions. With a cumulative contribution of $71.1 \%$ to the observed variation in grain yield, this suggests that these traits can be used in selection programmes as secondary traits for yield improvement under drought stress. Grain yield is therefore expected to increase in response to an increase in any of the traits. Badu-Apraku et al. (2012a) had earlier identified EA, PA, ASI, PH, EH, DS and EPP among some extra early maturing inbred lines as secondary traits to be considered during selection under drought conditions.

Under well-watered condition, EPP also had the highest contribution of $31.42 \%$ to grain yield followed by EA, PA, DP, DS and PH which contributed 15.94, 5.37, $3.13,10.7$ and $0.037 \%$ respectively with a cumulative total of $56.97 \%$. Similar to drought stress condition, a contribution of these traits was highly significant $(\rho \leq 0.01)$ except DS which was significant at $5 \%$ probability level. This is an indication of the level to which these traits are able to influence yield under well-watered condition. EPP has proven to be a trait to be considered when improvement is being carried out for grain yield under both drought stress and well-watered conditions (Bazinger et al., 2000).

Grain yield is complex being an effect of the interrelatedness of several other plant components that influences growth and development, thus deducing with reference to the method of accumulation, combination of its processes through its life cycle proves difficult (Anjum et al., 2011). Tadesse et al. (2018) hypothesized that selection based on simple correlation without taking into cognisance the direct effect of the one variable (independent) on the other (dependent) is ineffective in determining the actual interrelatedness among traits. The use of path coefficient analysis will therefore aid the breeder in deciphering the cause, consequences and importance of the variables therefore providing a more effective means of interpreting the association.

The partitioning of genotypic correlation coefficient with path coefficient analysis showed that DS, PH, PA, 


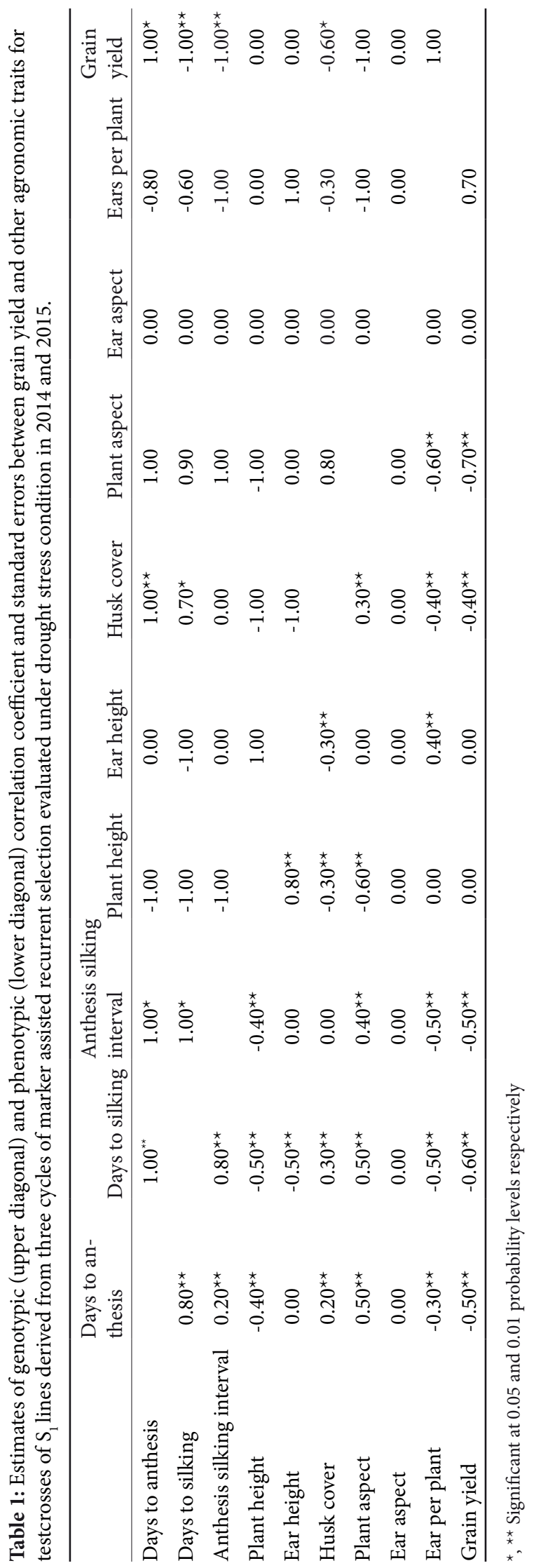

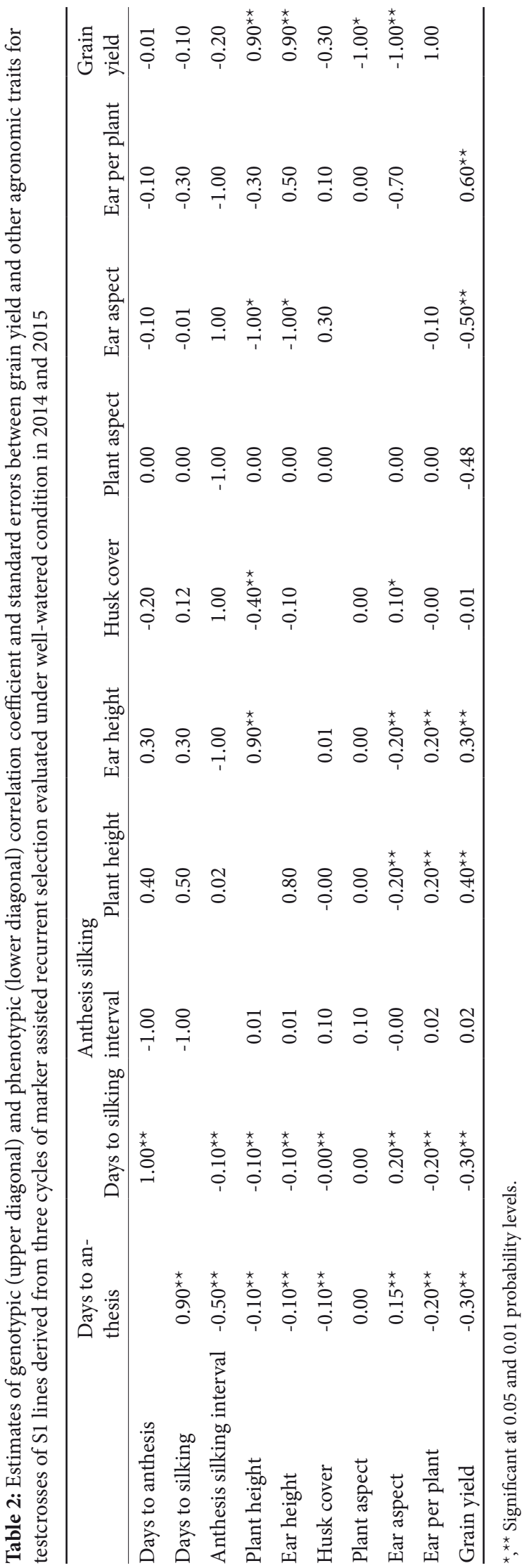




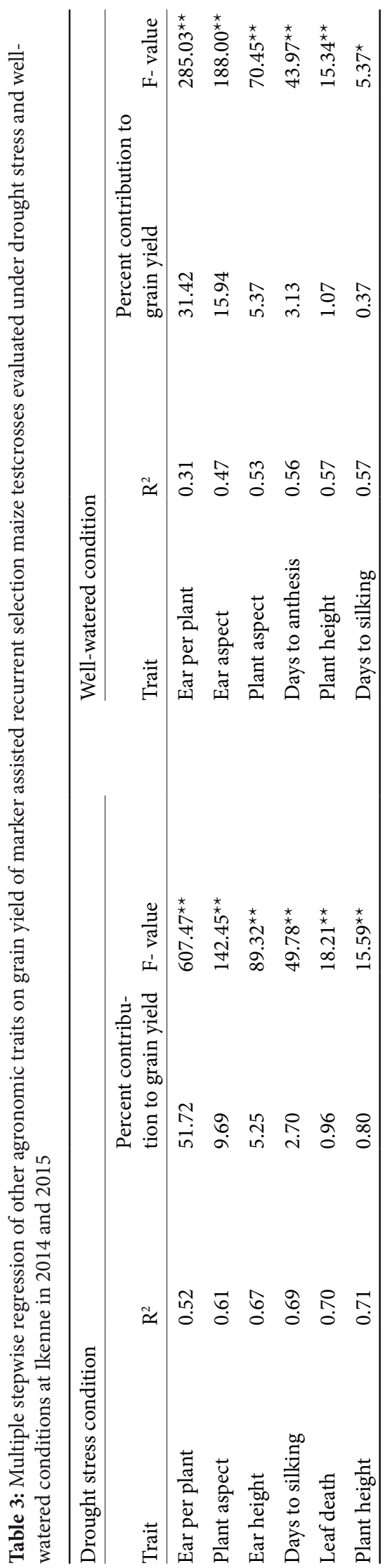

EA, LD and EPP as having a direct effect on GY. These six first order traits were recognized as being important in contributing to the observed variation in GY as shown from the path coefficient analysis (Fig 1) thus signifying them as potential secondary traits used as a selection criterion under drought stress. These findings corroborate those of Talabi et al. (2016) who identified EA, EPP, PA, STGR, DS, EHT and SL as traits with direct significant traits affecting GY under drought stress conditions.

EPP had the highest direct effect (0.37) on GY followed by DS (0.22) under drought stress condition. However, only the effects of EPP and PH were positive while the other direct effects were negative. Four traits (DP, ASI, EH and HC) also made contributions to GY but the contributions were indirect through DS (DP and ASI), PH (EH and HC), PASP (DP and EH) and EPP (DP, ASI, EH). $\mathrm{EH}$ and $\mathrm{HC}$ also contributed indirectly to grain yield through LD. ASI a known secondary trait contributed to GY indirectly through the six first order traits indicating that it should be considered as trait of importance during selection under drought stress. DP had the highest indirect positive effect on GY through DS (0.74) followed by EH through PH (0.73). The high coefficient reported for EPP corroborates the findings of Badu Apraku et al. (2018) who reported the highest path coefficient for EPP among extra early maize cultivars under drought stress conditions.

Under well-watered condition, the first order traits include EPP, EA, PA, DP and PH (Fig 2) with EPP (0.56) having the highest direct effect among the traits followed by EA $(-0.40)$. Similar to the result under drought stress, only EPP and PH had positive direct effect on GY while other first order traits were also negative. None of the second order traits which include DP, ASI, EH and HC made contributions through all the first order traits simultaneously. DS had the highest contribution to GY through DP (0.91) followed by the contributions of EH through $\mathrm{PH}(0.87)$.

Increased EPP together with some other traits had been identified as a secondary trait used as a selection criterion (Bazinger et al., 1997) under drought stress conditions, including $\mathrm{PH}$ which also had a direct positive effect on GY. Selection for increased EPP may be accomplished without an adverse effect under well-watered condition, but selection for increased plant height though may aid the plant to synthesize more assimilates resulting in production of more grains but usually at a price. Increased plant height usually predisposes the plant to lodging which adversely affects grain production. The proportion of the variation in the dependent variable that is influenced by the other variables (independent) is less than half under drought as reflected by the coefficient of determination. The high positive and direct effect of plant 
DROUGHT

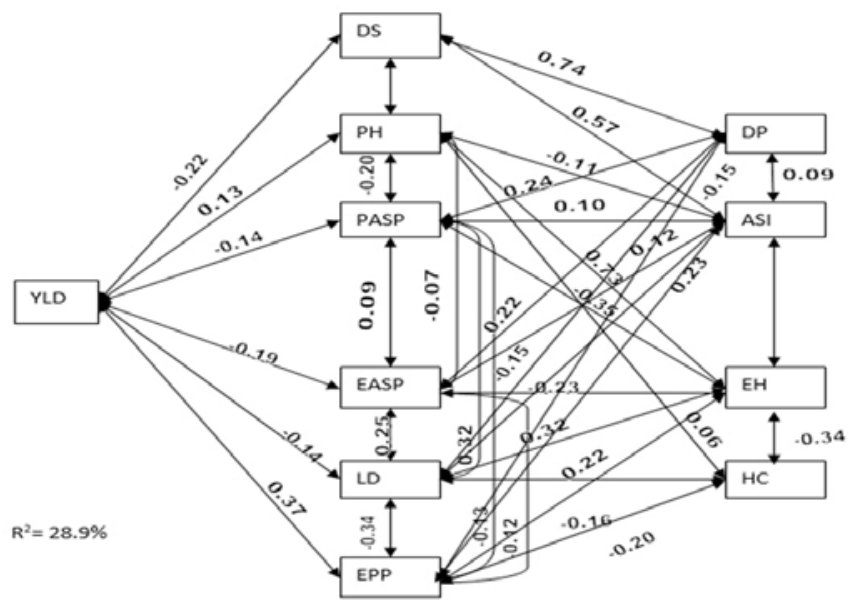

Figure 1: Path analysis diagram showing contributing associations of measured traits of testcrosses of S1 lines of marker assisted recurrent selection evaluated under drought conditions at Ikenne in 2014 and 2015. YLD, yield; ASI, anthesis-silking interval; DP, days to anthesis; DS, days to silking; EASP, ear aspect; EPP, ears per plant; PASP, plant aspect; PH, plant height; EH, ear height; LD, leaf death; HC, husk cover.

height on the yield corroborates the findings of Adesoji et al. (2015) who reported the highest positive and direct effect of plant height to grain yield in a maize population grown under legume incorporation and nitrogen. Therefore, the use of $\mathrm{PH}$ as a selection criterion may not be practical due to its non-beneficial effect on production of grains.

Under well-watered condition, the first order traits include EPP, EA, PA, DP and PH (Fig 2) with EPP (0.56) having the highest direct effect among the traits followed by EA (-0.40). Similar to the result under drought stress, only EPP and PH had positive direct effect on GY while other first order traits were also negative. None of the second order traits which include DP, ASI, EH and HC made contributions through all the first order traits simultaneously. DS had the highest contribution to GY through DP (0.91) followed by the contributions of EH through PH (0.87).

\section{OPTIMUM}

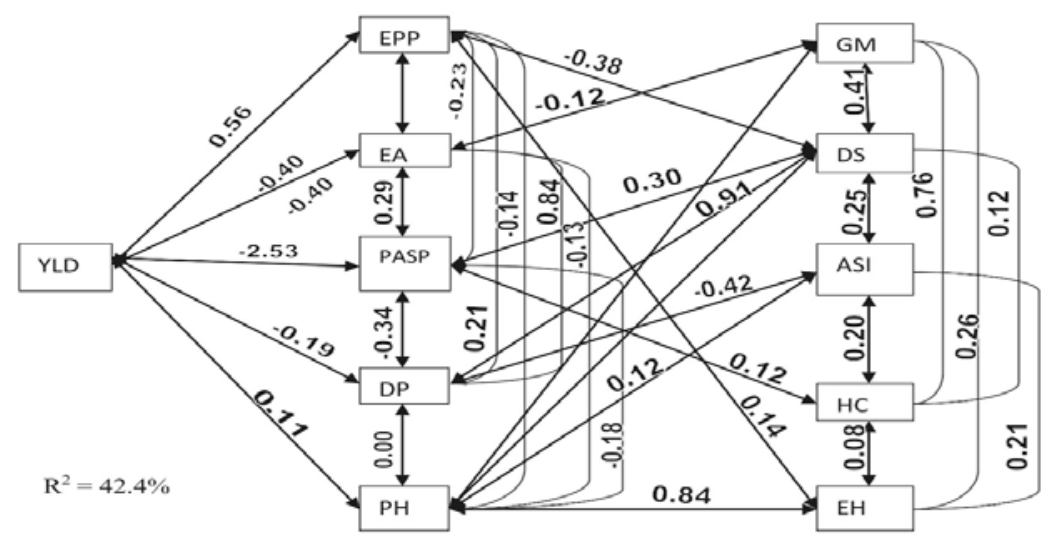

Figure 2: Path analysis diagram showing contributing associations of measured traits of testcrosses of S1 lines of marker assisted recurrent selection evaluated under well-watered conditions at Ikenne in 2014 and 2015. YLD, yield; ASI, anthesis-silking interval; DP, days to anthesis; DS, days to silking; EASP, ear aspect; EPP, ears per plant; PASP, plant aspect; $\mathrm{PH}$, plant height; EH, ear height; HC, husk cover. 
Increased EPP together with some other traits had been identified as a secondary trait used as a selection criterion (Bazinger et al., 1997) under drought stress conditions, including $\mathrm{PH}$ which also had a direct positive effect on GY. Selection for increased EPP may be accomplished without an adverse effect under well-watered condition, but selection for increased plant height though may aid the plant to synthesize more assimilates resulting in production of more grains but usually at a price. Increased plant height usually predisposes the plant to lodging which adversely affects grain production. The proportion of the variation in the dependent variable that is influenced by the other variables (independent) is less than half under well-watered condition as reflected by the coefficient of determination.

The high positive and direct effect of plant height on the yield corroborates the findings of Adesoji et al. (2015) who reported the highest positive and direct effect of plant height to grain yield in a maize population grown under legume incorporation and nitrogen. Therefore, the use of $\mathrm{PH}$ as a selection criterion may not be practical due to its non-beneficial effect on production of grains.

\section{CONCLUSION}

It can be concluded that though varying results were obtained with the use of correlation with respect to the measured traits associated with grain yield under both conditions, similar results were however obtained for the MARS testcrosses under both conditions with the use of multiple stepwise regression and path coefficient analysis. The coefficient of determination however showed variation: with the use of regression the dependent trait influenced the first order traits more under drought condition but reverse was the case with the use of path analysis. Ear aspect, plant aspect and ears per plant were identified as secondary traits that will aid selection for improved yield of maize. Leaf death; which is not one of the observed traits under well-watered condition was also identified as a secondary trait under drought stress. These traits are rated based on phenotypic appeal therefore their determination is highly subjective. Extra caution should therefore be taken when scoring to increase precision.

\section{ACKNOWLEDGEMENT}

I acknowledge all the staff of the Maize Improvement Programme and the Bioscience centre at the International Institute of Tropical Agriculture for helping me out in innumerable ways during the Field and laboratory facets of the work.

\section{REFERENCES}

Anjum S.A., L.C. Wang, M. Farooq, M. Hussain, L.L. Xue and C.M. Zou (2011). Brassinolide application improves the drought tolerance in maize through nodulation of enzymatic antioxidant and leaf gas exchange. Journal of Agronomy and crop science, 197, 177-185. https://doi. org/10.1111/j.1439-037X.2010.00459.x

Asima Gazal, Zahoor Ahmed Dar, Ajaz Ahmad Lone, Nida Yousuf and Shazia Gulzar (2018). Studies on Maize Yield under Drought Using Correlation and Path Coefficient Analysis. Internantional Journal of Current Microbiology and Applied Science, 7(01), 516-521. https://doi.org/10.20546/ijcmas.2018.701.062

Badu-Apraku B., A. O. Talabi, B. E. Ifie, Y. C. Chabi, K. ObengAntwi, A. Haruna, and R. Asiedu (2018). Gains in Grain Yield of Extra-Early Maize during Three Breeding Periods under Drought and Rainfed Conditions. Crop Science. https://doi.org/10.2135/cropsci2018.03.0168

Badu-Apraku, B., R.O. Akinwale, J. Franco, and M. Oyekunle. (2012a). Assessment of reliability of secondary traits in selecting for improved grain yield in drought and low nitrogen environments. Crop Science, 52, 2050-2062. https:// doi.org/10.2135/cropsci2011.12.0629

Badu-Apraku, B., M.A.B. Fakorede, A. Menkir, A.Y. Kamara, L. Akanvou, and Y. Chabi. (2004). Response of early maturing maize to multiple stresses in the Guinea savanna of West and Central Africa. Journal of Genetics and Breeding, 58, 119-130.

Bankole F., A. Menkir, G. Olaoye, J. Crossa, S. Hearne, N. Unachukwu and M. Gedil (2017). Genetic gains in grain yield and other traits in a maize population improved using marker assisted recurrent selection. Frontiers in plant science. https://doi.org/10.3389/fpls.2017.00808

Bänziger M., H.R. Lafitte (1997a). Efficiency of secondary traits for improving maize for low-nitrogen target environments. Crop Science, 37, 1110-1117. https://doi.org/10.2135/crops ci1997.0011183X003700040013x

Barata C, M.J. Carena (2006). Classification of North Dakota maize inbred lines into heterotic groups based on molecular and testcross data. Euphytica, 151, 339-349. https://doi. org/10.1007/s10681-006-9155-y

Baretta D, M. Nardino, I.R. Carvalho and R. Nornberg (2016). Path analysis for morphological characters and grain yield of maize hybrids. Australian. Journal of Crop Science, 10, 1655-1661. https://doi.org/10.21475/ajcs.2016.10.12.p7707

Barima, Y.S. D. Angaman, K. N'gouran, N. KoffI, F. Kardel, C. DE Cannière, R. Samson, (2014). Assessing atmospheric particulate 25 matter distribution based on Saturation Isothermal permanent magnetization of herbaceous and tree leaves in a tropical urban environment. Science of the Total Environment, 975-982. https://doi.org/10.1016/j.scitotenv.2013.10.082

Barros L.B., Moreira R.M.P., Ferreira J.M. (2010) Phenotypic, 
additive genetic and environment correlations of maize landraces populations in family farm systems. Scientia Agricola (Piracicaba, Braz.), 67, 685-691. https://doi.org/10.1590/ S0103-90162010000600010

Bänziger, M., G.O. Edmeades, D. Beck, and M. Bellon. (2000). Breeding for Drought and Nitrogen Stress Tolerance in Maize: From Theory to Practice. Mexico, D.F.: International Maize and Wheat Improvement Centre (CIMMYT)

Begum, S., A. Ahmed, S.H. Omy, M.M. Rohman. and M. Amiruzzaman (2016). Genetic Variability, Character Association and Path Analysis in Maize (Zea mays L.). Bangladesh Journal of Agricultural Research, 41, 173-182. https:// doi.org/10.3329/bjar.v41i1.27682

Betrán F. J., D. Beck, M. Bänziger and G.O. Edmeades (2003). Genetic analysis of inbred and hybrid grain yield under stress and non-stress environments in tropical maize. Crop Science, 43, 807-817. https://doi.org/10.2135/cropsci2003.0807

Bolaños J., G.O. Edmeades (1996). The importance of the anthesis-silking interval in breeding for drought tolerance in tropical maize. Field Crops Research, 48, 65-80. https://doi. org/10.1016/0378-4290(96)00036-6

Bolaños J., G.O. Edmeades (1993). Eight cycles of selec $\neg$ tion for drought tolerance in tropical maize II. Responses in reproductive behaviour. Field Crop Research, 31, 253-268. https://doi.org/10.1016/0378-4290(93)90065-U

Boyer J. and M. Westgate (2004). Grain yields with limited water. Journal of Experimental Botany, 55, 2385-2394. https:// doi.org/10.1093/jxb/erh219

Byrne, P.F., J. Bolanos, G.O. Edmeades, D.L. Eaton (1995). Gains from selection under drought versus multilocation testing in related tropical maize populations. Crop Science, 35, 63-69. https://doi.org/10.2135/cropsci1995.0011183X0 03500010011x

Cattivelli L., F. Rizza, F.W. Badeck, E. Mazzucotelli, A.M. Mastrangelo, E. Francia E., C. Mare, A. Tondelli, A.M. Stanca (2008). Drought tolerance improvement in crop plants: An integrative view from breeding to genomics. Field Crop Research, 105, 1-14. https://doi.org/10.1016/j.fcr.2007.07.004

Cooper M., C. Gho, R. Leafgren, T. Messina (2014). Breeding drought-tolerant maize hybrids for the US corn-belt: discovery to product. Journal of Experimental Botany, 65, 6196-6204. https://doi.org/10.1093/jxb/eru064

Derera J., Tongoona, P., Vivek, B.S., Laing, M.D. (2008). Gene action controlling grain yield and secondary traits in southern African maize hybrids under drought and nondrought environments. Euphytica, 162, 411 422. https://doi. org/10.1007/s10681-007-9582-4

Dewey, D.R., and K.H. Lu. (1959). A correlation and path co-efficient analysis of components of crested wheat seed produc $\neg$ tion. Agronomy Journal, 51, 515-518. https://doi. org/10.2134/agronj1959.00021962005100090002x

Edmeades, G.O., Bolaños, J., Chapman, S.C., Lafitte, H.R. and M. Bänziger (1999). Selection improves drought tolerance in tropical maize populations: Gains in biomass, grain yield and harvest index. Crop Science, 39, 1306-1315. https:/doi. org/10.2135/cropsci1999.3951306x

Edmeades G.O., Banziger, M., Chapman, S.C., Ribaut, J.M. and J. Bolanos (1995). Recent Advances in Breeding for
Drought Tolerance in Maize. In B. Badu-Apraku et al. (ed.) Contributing to food self-sufficiency: Maize Research and Development in West and Central Africa. Proc. of Regional Maize Workshop. 28 May-2 June 1995. IITA-Cotonou, Benin Republic. IITA, Ibadan, Nigeria. pp. 24-41.

FAO. (2010). The state of food insecurity in the world. Addressing food insecurity in protracted crises. Available at http:// www.fao.org/publications/sofi /en/ (verified 10

Frey F.P., Urbany, C., Hüttel, B., Reinhardt, R. and B. Stich (2015). Genomewide expression profiling and phenotypic evaluation of European maize inbreeds at seedling stage in response to heat stress. BMC Genomics,16,123. https://doi. org/10.1186/s12864-015-1282-1

Gong F, Wu, X., Zhang, H., Chen, Y. and W. Wang (2015). Making better maize plants for sustainable grain production in a changing climate. Frontiers in Plant Science, 6, 835. https:// doi.org/10.3389/fpls.2015.00835

Holland J.B. (2006). Estimating genotypic correlations and their standard errors using multivariate restricted maximum likelihood estimation with SAS Proc MIXED. Crop science, 46, 642-654. https://doi.org/10.2135/cropsci2005.0191

Horton D.E., Johnson, N.C., Singh, D., Swain, D.L., Rajaratnam, B. and N.S. Diffenbaugh (2015). Contribution of changes in atmospheric circulation patterns to extreme temperature trends. Nature, 522, 465-469. https://doi.org/10.1038/nature 14550

Kolawole A.O., Menkir, A. Blay, E. Ofori, K. and J. Kling (2018). Genetic advance in grain yield and other traits in two tropical maize composites developed via reciprocal recurrent selection. Crop Science 58:2360-2369 https://doi. org/10.2135/cropsci2018.02.0099

Lobell D.B., M. Bänziger, C. Magorokosho B. Vivek (2011). Non-linear heat effects on African maize as evidenced by historical yield trials. Nature Climate Change, 1, 42-45. https://doi.org/10.1038/nclimate1043

Lobell D.B., Roberts, M.J. Schlenker, W. Braun, N. and B.B. Little (2014). Greater sensitivity to drought accompanies maize yield increase in the U.S. Midwest. Science, 344, 516519. https://doi.org/10.1126/science.1251423

Malik H.N., Malik, S.I. Hussain, M. Chughtai, S.R. and H.I. Javed (2005). Genetic correlation among many quantitative characters in maize (Zea mays) hybrids. Journal of Agriculture and social sciences, 1(3), 262-265.

Matin, M.Q., Uddin, M., Rohman, M., Amiruzzaman, M., Azad, A. and B. Banik (2017). Genetic Variability and Path Analysis Studies in Hybrid Maize (Zea mays L.). American Journal of Plant Sciences, 8, https://doi.org/10.4236/ ajps.2017.812209

Menkir, A. (2008). Genetic variation for grain mineral content in tropical adapted maize inbred lines. Food chemistry, 110 , 454-464. https://doi.org/10.1016/j.foodchem.2008.02.025

Messmer R., Fracheboud, Y., Banziger, M., Vargas, M., Stamp, P. and J.M. Ribaut (2009). Drought stress and tropical maize: QTL-by-environment interactions and stability of QTLs across environments for yield components and secondary traits. Theoretical and Applied Genetics, 119, 913-930. https://doi.org/10.1007/s00122-009-1099-x

Mhike X., Okori, P., Magorokosho, C. and K. Semagn (2013). QTL mapping for morpho-physiological traits of MARS 
targeted maize biparental crosses under moisture stress and non-stress environments. 11th African Crop Science Proceedings, Sowing innovations for sustainable food and nutrition security in Africa., Uganda, 14-17 October, 2013, pp.553-558 ref.19 Entebbe.

Mohammadai H., Soleymani, A. and M. Shams (2012). Evaluation of Drought Stress Effects on Yield Components and Seed Yield of Three Maize Cultivars (Zea mays L.) in Isfahan region. International Journal of Agriculture and Crop Sciences, 4(19), 1436-1439.

Mohammadi R., Amri, A. and M. Nachit (2011). Evaluation and Characterization of International Durum Wheat Nurseries under Rainfed Conditions in Iran. International Journal of Plant Breeding, 5(2), 94-100.

Mohammadi R, Armion, M. Kahrizi, D. and A. Amri (2010). Efficiency of screening techniques for evaluating durum wheat genotypes under mild drought conditions. Journal of Plant Production, 4(1), 11-24.

Mohammadia, S.A., Prasanna, B. M. and N.N. Singh (2003). Sequential path model for determining interrelationship among grain yield and related characters in maize. Crop Science, 43, 1690-1697. https://doi.org/10.2135/cropsci2003.1690

Najafian G. (2009). Drought tolerance indices, their relationships and manner of application to wheat breeding programmes. In: Mohammadi R, Haghparast R (Eds) Plant Science in Iran. Middle Eastern and Russian Journal of Plant Science and Biotechnology, 3(Special Issue 1), 25-34.

Nouri A, Etminan, A. Teixeira da Silva, J.A. and R. Mohammadi (2011). Assessment of yield, yield-related traits and drought tolerance of durum wheat genotypes (Triticum turjidum var. durum Desf.). Australian Journal of Crop Science, 5(1), 8-16.

Ober E.S. (2008). Breeding for improved drought tolerance and water use efficiency in HGCA (Eds): Arable cropping in a changing climate HGCA Higham, pp 28 - 37.

Olaoye G. (2009). Evaluation of new generations of maize streak virus (msv) resistant varieties for grain yield, agronomic potential and adaptation to Southern Guinea savanna ecology of Nigeria. Journal of Tropical Agriculture, Food, Environment and Extension, 8(2), 104-109. https:// doi.org/10.4314/as.v8i2.51107

Ort D. and S. Long (2014). "Limits on Yields in the Corn Belt." Science, 344, 484-85. https://doi.org/10.1126/science. 1253884

Rajaram S. and M. Van Ginkle (2001). Mexico, 50 years of international wheat breeding. In Bonjean A.P., and Angus W.J. (eds) The world Wheat Book, A History of Wheat Breeding, Paris, France. Lavoisier Publishing, pp 579-604.

Ribaut J.M., Jiang, C., Gonzalez-de-Leon, D., Edmeades, G.O. and D.A. Hoisington (1997). Identification of quantitative trait loci under drought conditions in tropical maize. 2. Yield components and marker-assisted selection strategies. Theoretical and Applied Genetics, 94, 887-896. https://doi. org/10.1007/s001220050492
SAS Institute (2009). SAS system for Windows v. 9.3. SAS Inst. Inc., Cary, NC.

Semagn K, Beyene, Y., Babu, R., Nair, S. Gowda, M.,Das, . B., Tarekegne, A., Mugo, S., Mahuku, G., Worku, M., Warburton, M.L., Olsen, M. and B.M. Prasanna (2015). Quantitative trait loci mapping and molecular breeding for developing stress resilient maize for sub-Saharan Africa. Crop Science, 55, 1-55. https://doi.org/10.2135/cropsci2014.09.0646

Sio-Se Mardeh A., Ahmadi, A., Poustini, K. and V. Mohammadi (2006). Evaluation of drought resistance indices under various environmental conditions. Field Crop Research, 98, 222-229. https://doi.org/10.1016/j.fcr.2006.02.001

Tadesse L., Mekbib, F., Wakjira, A. and Z. Tadele (2018). Correlation and path coefficient analysis of yield and quality components of garden cress (Lepidium sativum L.) genotypes in Ethiopia. Journal of Plant Breeding and Crop Science, 10(10), 290-297. https://doi.org/10.5897/JPBCS2018.0757

Talabi, A.O., Badu-Apraku, B. and M.A.B. Fakorede. (2017). Genetic variances and relationship among traits of an earlymaturing maize population under drought-stress and low $\mathrm{N}$ environ $\neg$ ments. Crop Science, 57, 681-692. https://doi. org/10.2135/cropsci2016.03.0177

Tardieu F. and R. Tuberosa (2010). Dissection and modeling of abiotic stress tolerance in plants. Current Opinion in Plant Biology, 13, 206-212. https://doi.org/10.1016/j. pbi.2009.12.012

Ti-da G.E., Fang-Gong, S.U.I. and B.A. Ping (2006). Effects of water stress on the protective enzymes and lipid peroxidation in roots and leaves of summer maize. Agricultural Science China, 5, 291-298. https://doi.org/10.1016/S16712927(06)60052-7

Venuprasad R., Lafitte, H.R. and G.N. Atlin (2007). Response to direct selection for grain yield under drought stress in rice. Crop Science, 47, 285-293. https://doi.org/10.2135/ cropsci2006.03.0181

Williams A.P. and C. Funk. (2011). A westward extension of the warm pool leads to a westward extension of the Walker circulation, drying eastern Africa. Climate Dynamics, 37, 2417-2430. https://doi.org/10.1007/s00382-010-0984-y

Wright, S. (1921). Correlation and Causation. Journal of Agricultural Research, 20, 557-585.

Xoconostle-Cazares B, Ramirez-Ortega, F.A., Flores-Elenes, L. and R. Ruiz Medrano (2011). Drought tolerance in crop plants. American Journal of Plant Physiology. ISSN 15574539

Zheng J., Wu, A.Z., A.Z. Zheng, A.Z., Wang, Y.F., Cai, R., Shen, X.F., Xu, R.R., Liu, P., Kong, L.J. and S.T. Dong (2009). QTL mapping of maize (Zea mays) stay-green traits and their relationship to yield. Plant Breeding, 128, 54-62. https://doi. org/10.1111/j.1439-0523.2008.01529.x

Ziyomo C. and R. Bernardo (2013). Drought tolerance in maize: indirect selection through secondary traits versus genome wide selection. Crop Science, 53, 1269-12. https:// doi.org/10.2135/cropsci2012.11.0651. 